\title{
PENTINGNYA IMPLEMENTASI NILAI PANCASILA AGAR TIDAK TERJADI PENYIMPANGAN DALAM MASYARAKAT LUAS
}

\author{
Aulia Nur Hakim \& Dinie Anggraeni Dewi \\ Universitas Pendidikan Indonesia \\ aulianh@upi.edu
}

\begin{abstract}
Abstrak
Kurangnya kesadaran pengimplementasian nilai pancasila dalam kehidupan masyarakat membuat ideology pancasila tersisihkan. Penyimpangan terhadap nilai pancasila masih sering terjadi di dalam kehidupan bernegara dan tidak mencerminkan sikap yang sesuai pancasila. Tujuan penelitian ini adalah untuk mengetahui bagaimana peran Pancasila dalam membangun karakter bangsa, mengkaji permasalahan atau urgensi pengimplementasian setiap makna yang terkandung dalam nilai pancasila serta menginternalkan atau mengimplementasikan Pancasila melalui mata kuliah Pendidikan Pancasila. Melalui mata kuliah tersebut, mahasiswa diharapkan dapat menjadi generasi penerus bangsa menjadi manusia yang bermutu, bermoral, berjiwa pancasilais dan dapat membumikan setiap nilai-nilai pancasila. Tidak hanya mahasiswa namun masyarakat juga perlu ditanamkan jiwa pancasilais. Metode penelitian yang digunakan disini adalah metode kualitatif yaitu menggunakan cara menganalisis atau mengkaji data yang sudah ada. Hasil dari penelitian ini menunjukkan jika pengimplementasian setiap nilai yang ada dalam pancasila belum terealisasikan dengan baik, terlihat dari sejumlah kasus yang telah terjadi di Indonesia dari tahun-tahun yang lalu yang menggambarkan ketidakseimbangan antara nilai pancasila dengan pengaktualisasiannya sehingga hal tersebut perlu menjadi perhatian khusus pemerintah dan warga negara agar dapat menjalankan setiap nilainya dengan benar
\end{abstract}

Kata Kunci: Penyimpangan Nilai Pancasila, Implementasi Nilai Pancasila, Membangun Karakter Bangsa

\begin{abstract}
Lack of awareness of the implementation of Pancasila values in people's lives has made the Pancasila ideology marginalized. Deviations to the value of Pancasila still often occur in state life and do not reflect attitudes that are in accordance with Pancasila. The purpose of this research is to find out how the role of Pancasila in building the character of the nation, then to study the problems or urgency of implementing each meaning contained in the values of Pancasila and internalizing or implementing Pancasila through the Pancasila Education course. Through these courses, students are expected to become the nation's next generation to become human beings with quality, moral, Pancasila spirit and can ground every Pancasila values. Not only students but the community also needs to instill a Pancasila spirit. The research method used here is a qualitative method, namely using a way of analyzing or reviewing existing data. The results of this study show that if the implementation of each value in Pancasila has not been well realized, it can be seen from a number of cases that have occurred in Indonesia from the past years which illustrate the imbalance between the value of Pancasila and its actualization so that this needs to be of special concern to the government and citizens in order to be able to carry out each of its values properly

Key Words: Deviation of Pancasila Values, Implementation of Pancasila Values, Build national character
\end{abstract}

\section{PENDAHULUAN}

Schubert (2002) dalam buku (Nurdin dan Usman (2002:70) menjelaskan jika implementasi yaitu sebuah rekayasa sistem untuk mencapai suatu tujuan tertentu. Implementasi mengarah kepada kegiatan, aksi maupun mekanisme dari sebuah sistem. Mekanisme disini berarti bahwa jika implementasi bukan hanya aktivitas saja namun adalah suatu kegiatan yang telah direncanakan dan dilaksanakan dengan serius berdasarkan prosedur khusus agar dapat meraih tujuan dari kegiatan tersebut. Dapat dikatakan jika implementasi yaitu aksi yang dilaksanakan pihak yang berhak dan berkepentingan, 
entah itu pihak pemerintah ataupun pihak swasta yang memiliki tujuan untuk merealisasikan harapan dan capaian lain yang sudah diatur (Nurgiansah, 2020b).

Pancasila adalah pemikiran serta keyakinan hidup dalam diri masyarakat Indonesia. Dalam Pancasila terdapat rumusan poin dasar mengenai Ketuhanan, alam, dan manusia yang dijelaskan secara rinci. Warga negara harus mengetahui, memahami dan menerapkan nilai Pancasila dalam segala kegiatan hidupnya. Dengan adanya ideologi Pancasila hal ini malah membuat Indonesia merasa dijatuhkan oleh masyarakatnya.

Contohnya yaitu seperti menggunakan Pancasila untuk ikon pelaksanaan upacara pada hari Senin dan peringatan hari besar nasional kebangsaan lainnya tanpa mereka memahami maknanya. Terlebih lagi sekarang banyak pengaruh budaya asing yang hadir di negara Indonesia dan menjadikan ideology Pancasila tergeserkan, hingga bisa memungkinkan ideology bangsa Indonesia yaitu Pancasila akan hilang dari jiwa para generasi muda di zaman sekarang. Sebagai penerus bangsa seharusnya kita dapat mencegah hal tersebut terjadi agar Indonesia tetap kokoh dan tidak kehilangan jadi dirinya (Nurgiansah, 2021b).

Tujuan penelitian ini adalah untuk mengetahui bagaimana peran pancasila dalam membangun karakter bangsa, lalu mengkaji permasalahan atau urgensi pengimplementasian setiap makna yang terkandung dalam pancasila serta menginternalkan atau mengimplementasikan Pancasila melalui mata kuliah Pancasila. Wawasan mahasiswa terhadap Pancasila saat ini mulai berkurang, sampai-sampai ada mahasiswa yang tidak mengetahui kandungan dari setiap sila dalam Pancasila (Dewantara \& Nurgiansah, 2021).
Kejadian tersebut mengakibatkan pengaktualisasian nilai Pancasila dalam kehidupan sukar dicapai. Seharusnya mahasiswa sebagai garda terdepan penyambung harapan dan tekad para pendiri bangsa sangatlah diharapkan keikutsertaan untuk menerapkan kandungan nilai Pancasila di kehidupan bernegara. Dapat dikatakan bahwa dalam pendidikan Pancasila, penerapan nilai kebajikan kepada mahasiswa tak hanya mengacu pada segi pengetahuan saja, namun juga segi kemauan dan kesadaran, serta sikap kesadaran diri untuk mengamalkan nilai-nilai itu agar dapat menjadi manusia yang utuh.

Pada kenyataannya, perilaku menyimpang sering dijumpai di masyarakat sebagai bukti dari kesenjangan indikator penerapan nilai Pancasila. Pelaksanaan nilai Pancasila di lapangan juga hadir dalam masyarakat agar dapat memberi gambaran pedoman yang harus dipegang dan dilaksanakan oleh setiap masyarakat Indonesia (Dewantara, Hermawan, et al., 2021).

(Fitri Anggriani, 2018) Nilai-nilai Pancasila mulai luntur dalam diri masyarakat Indonesia seiring berjalannya waktu. Pancasila telah dikenali pada masa kerajaan dimana nilai-nilai dari pancasila sudah diaktualisasikan baik itu di masyarakat atau di kerajaan, meski belum dibentuk secara nyata (Darmawan, 2018). Segala sesuatu yang dilakukan masyarakat dilandaskan kepada Pancasila karena Pancasila adalah Ideologi negara Indonesia Pancasila berperan sebagai penyatu bangsa yang panca ragam suku, ras, budaya dari Sabang hingga Merauke. Kemunculan pendidikan karakter atau watak dinilai sebagai sesuatu yang niscaya oleh para ahli.

Misalnya, John Sewey (1916) menyatakan jika membentuk karakter dalam teori pendidikan adalah suatu hal yang biasa yang memiliki tujuan umum 
mengajarkan dan mendidik tentang budi pekerti di lembaga pendidikan. Pendidikan karakter juga memiliki fungsi sebagai pengembang atau pembentuk karakter dan peradaban bangsa yang berguna untuk mencerdaskan kehidupan bangsa Indonesia.

(Suparlan: 2012) Pancasila merupakan ideology bangsa Indonesia yang berperan sebagai dasar maupun landasan untuk setiap lembaga masyarakat, politik dan hukum di Indonesia. Pendidikan karakter perlu ditanamkan kepada masyarakat agar dapat membentuk watak yang baik dan sesuai dengan Pancasila.

Archipelago menerangkan dibuku Yudilatif (Negara Paripurna, 2012:2) jika Pancasila yaitu suatu aset nasional yang sejalan dengan kekhasan alam yang mempunyai laut berisi kumpulan pulau. Ini mengandung arti jika Pancasila adalah rehabilitasi berbagai macam ras, suku, adat, budaya, dan agama yang ada di tanah air tanpa mengucilkan siapapun. Notonegoro berpendapat jika Pancasila merupakan pedoman hidup bangsa Indonesia dan memiliki peran sebagai pemersatu dan pertahanan bangsa. (Dewantara. A, Diskursus filsafat pacasila dewasa ini, 2017, hal. 13) Pancasila adalah falsafat bangsa Indonesia, yang berarti jika kegiatan berbangsa dan bernegara, semuanya didasarkan oleh nilai ketuhanan, kemanusiaan, persatuan, kerakyatan serta Keadilan. Pemikiran ini berbeda dengan pandangan jika negara merupakan sebuah persekutuan hidup manusia maupun organisasi dari masyarakat dimana mereka adalah masyarakat hukum.

Natonegoro juga menyebutkan jika setiap nilai Pancasila tergolong nilai rohani, namun nilai rohani yang membenarkan nilai material dan vital. Pancasila termasuk ke dalam nilai kerohanian yang memiliki nilai-nilai yang komplit seperti nilai kebaikan, keindahan, kesucian, moral dan nilai religius (Dewantara, Nurgiansah, et al., 2021). Semua nilai tersebut bersifat tersusun-hierarki, dimana sila satu mengenai ketuhanan sebagai dasar hingga sila kelima yaitu Keadilan sosial sebagai tujuannya (Darmodihardjo, 1978). Upaya pengimplementasian pendidikan pancasila sebagai rancangan usaha untuk menolong orang lain untuk paham, peduli serta berperilaku sejalan dengan nilai-nilai etika. Tujuan dari hal ini yaitu agar anak memiliki kepribadian yang lebih baik lagi dalam kehidupan berbangsa dan bernegara. Ramli menyebutkan (dalam Kemendiknas, 2010:13), implementasi dari pendidikan pancasila memiliki arti yang serupa dengan implimentasi pendidikan adab serta akhlak.

(Suwarno, 1993: 108) Agar konsistensi dalam mengimplementasikan nilai pancasila dimasyarakat tetap terjaga, maka Pancasila yang formal dan formal itu dimodifikasi menjadi pernyataan pancasila yang umum kolektif serta Pancasila yang terbatas individu. Kesimpulannya, pancasila yang asalnya bersifat subjek kelompok serta individu, maka akan menghayati segala perilaku di lingkungan praksisnya dalam semua sektor baik itu politik, kenegaraan atau pribadi.

\section{METODE PENELITIAN}

Penelitian ini menggunakan metode literature atau kajian pustaka terkait. Dengan membaca dan mengkaji dari berbagai literature atau pustaka yang sesuai dengan bidang penelitian yang sedang dibuat sehingga mempermudah peneliti dalam mencari hal-hal apa saja yang memiliki peluang untuk dilakukan penelitian. Kebiasaan membaca literature atau pustaka terkait maka ini akan sangat membantu peneliti untuk bereksplorasi dalam melakukan penelitian (Nurgiansah, 2021a).

Kriteria serta ketentuan harus dipenuhi dalam memilih suatu masalah 
penelitian. Ary, dkk.(2010) menyebutkan beberapa kriterianya yaitu: Masalah yang diteliti merupakan masalah yang sangat penting, Masalah seharusnya dapat menjadi sesuatu yang menimbulkan permasalahan baru untuk peneliti di masa mendatang, Masalah harus bisa diteliti, Masalah penelitian harus setara dengan kemampuan dari peneliti, dan Masalah peneliti harus sesuai dengan etika (Nurgiansah, 2020c).

\section{HASIL PENELITIAN DAN PEMBAHASAN Hasil Penelitian \\ Pancasila Sebagai Pembangun Karakter Bangsa Indonesia}

Maswardi Rauf (2008: 88) menjelaskan jika karakter bangsa yaitu sifat yang melekat dalam bangsa secara menyeluruh yang terlihat pada cara berpikir serta perilaku yaitu budaya maupun nilai yang dipercayai masyarakat untuk dijadikan pedoman saat berperilaku. Karakter bangsa bisa dibangun lewat budaya yang terdapat di masyarakat. Kemudian kultur atau budaya tersebut dapat melahirkan sebuah pandangan hidup bersama yang dikenal sebagai Pancasila. Karakter bangsa perlu dibina melalui nilainilai pancasila sehingga bangsa Indonesia dapat bersikap dan berperilaku sesusai dan dapat membawa bangsa kepada kesuksesan hidup seperti cita-cita bangsa (Nurgiansah, 2021c).

Nilai pancasila bisa memberi peran atas pengembangan kepribadian bangsa Indonesia dalam kehidupan bermasyarakat dan bernegara dalam segala aspek kehidupan. Pancasila terlahir dari nilainilai luhur. Pancasila menciptakan negara Indonesia lebih baik lagi yang berlandaskan kepada nilai ketuhanan, nilai kemanusiaan, nilai persatuan, nilai kerakyatan dan nilai keadilan. Dengan begitu setiap orang Indonesia harus paham dan mengaktualisasikan nilai-nilai pancasila dalam kesehariannya, dari mulai kegiatan sederhana. Contohnya masyarakat yang saling bergotong royong dalam membersihkan lingkungan, saling toleransi antar umat beragama dan lain-lain (Nurgiansah, 2021d).

Pentingnya penerapan nilai-nilai pancasila dalam lingkungan masyarakat perlu mendapat perhatian khusus oleh setiap masyarakat di Indonesia supaya tidak terjadi suatu hal yang dapat merugikan negara seperti halnya perpecahan. Dengan melakukan identifikasi melihat perilaku serta kepribadian masyarakat Indonesia, itu dapat menggambarkan bagaimana kondisi di Indonesia seperti yang terlihat pada kehidupan sehari-harinya. Globalisasi membawa pengaruh terhadap negara Indonesia, maka dari itu pembudayaan nilai pancasila sangatlah penting. Membangun karakter dengan Pendidikan pancasila dapat membantu peserta didik di berbagai tingkatan agar memiliki perilaku atau moral Pancasila yang sesuai (Nurgiansah \& Al Muchtar, 2018). Sehingga peserta didik mempunyai semangat dalam mewujudkan dan melaksanakan nilai praksis dalam Pancasila. Generasi muda sebagai generasi yang akan menjadi penerus bangsa harus mempunyai kecakapan intelektual dalam melakukan aktualisasi nilai-nilai pancasila secara tepat sebagai usaha responsive atas dinamika internal dan dinamika eksternal negara Indonesia. Pembangunan karakter bangsa telah terpikirkan oleh bangsa Indonesia melalui para pendiri negara jauh sebelum bangsa Indonesia merdeka. Bapak Ir.Soekarno sering mengatakan bahwa membangun karakter bangsa adalah hal yang sangat penting.

\section{Pembahasan}

Penyimpangan Yang Sering Terjadi Terhadap Nilai-Nilai Pancasila Penyimpangan Nilai Pancasila dalam Sila Ketuhanan Yang Maha Esa 
Sila pertama yaitu Ketuhanan Yang Maha Esa, mewujudkan perilakunya dalam menjalankan segala perintah ajaran agamanya masing-masing, saling toleransi antar umat beragama, mengamalkan ajaran agamanya dan memberi manfaat bagi kepentingan orang lain. Pernah terjadi kasus penyimpangan dalam sila ini seperti aksi radikal dari suatu kelompok yang menggunakan nama agama, tidak tercermin sikap toleransi terhadap sesama, pembunuhan dan lain sebagainya tidak mencerminkan sila Ketuhanan Yang Maha Esa. Seperti yang pernah terjadi di Surabaya, Jawa Timur mengenai kasus Bom Bunuh Diri yang ledakannya terjadi di 3 Gereja dengan alasan berjihad lalu disusul lagi oleh ledakan yang terjadi di Kantor Polisi yang mengakibatkan adanya korban. Aksi Terorisme yang terjadi di Indonesia ini bisa disebabkan oleh pemahaman mereka yang kurang terhadap nilai Pancasila yang sesungguhnya.

\section{Penyimpangan Nilai Pancasila dalam Sila Kemanusiaan Yang Adil dan Beradab}

Sila kemanusiaan yang adil dan beradab, perilakunya bisa dalam wujud saling menghargai derajat dan kedudukan manusia, saling mengasihi, kedudukan yang sama dalam hukum dan kemasyarakatan, dan saling menyayangi antar sesama sehingga tercapainya kondisi yang rukun dalam bermasyarakat. Hal ini juga berarti bahwa manusia memiliki jiwa keadilan, manusia sebagai makhluk tersempurna yang diciptakan oleh tuhan dengan diberi pikiran serta akal sehingga diharapkan dapat menjadi manusia yang adil serta bijaksana (Nurgiansah, 2020a).

Contoh kasus penyimpangan pada sila kedua ini adalah adanya penggusuran rumah warga yang miskin di Surabaya dan pemerintah tidak menindak lanjuti hal tersebut dengan adanya jaminan atau bantuan kepada warga yang tergusur. Hal ini membuat adanya tindakan perbudakan atau mempekerjakan anak dibawah umur yang merusak moral masyarakat Indonesia. Ketidakadilan pemerintah ini adalah wujud dari penyimpangan nilai sila kedua.

\section{Penyimpangan Nilai Pancasila dalam Sila Persatuan Indonesia}

Sila Persatuan Indonesia, diwujudkan dengan tidak adanya diskriminasi antar kepada suatu individu ataupun golongan, bersedia unuk saling bekerja sama, bergotong royong, rela berkorban dan lain-lain. Namun penyimpangan seperti aksi OPM atau Organisasi Papua Merdeka yang telah ada sejak tahun 1965 dan masih ada hingga saat ini. Gerakan ini memiliki tujuan agar dapat keluar dari wilayah Negara Kesatuan Republik Indonesia dan berkeinginan membentuk negaranya sendiri. Kasus ini adalah contoh pelanggaran dari sila ketiga.

\section{Penyimpangan Nilai Pancasila dalam Sila Kerakyatan Yang Dipimpin Oleh Hikmat Kebijaksanaan dalam Permusyawaratan/Perwakilan}

Sila ini dapat diwujudkan dalam bentuk menuntaskan permasalahan melalui musyawarah tanpa memaksa pendapat/keinginan orang lain, dan lain sebagainya. Namun masih sering ditemui kasus penyimpangan dari sila keempat ini seperti misalnya kasus seorang nenek tua yang mencuri singkong yang ditahan hingga bertahun-tahun, namun para oknum koruptor yang sangat merugikan negara tidak mendapat hukuman yang sepadan dan bahkan pernah ditemukan lapas koruptor yang mewah dengan fasilitas yang sangat nyaman. Hal ini perlu menjadi evaluasi pemerintah dalam menindak lanjuti adanya ketidakseimbangan atau ketidakadilan di negara ini. 


\section{Penyimpangan Nilai Pancasila dalam Sila Keadilan Sosial Bagi Seluruh Rakyat Indonesia}

Hingga saat ini penyimpangan dalam sila kelima sangat sering ditemui di kehidupan masyarakat. Contohnya adalah diskriminasi di dalam Rumah Sakit saat menangani pasien. Penulis juga sering melihat kejadian yang diskriminatif terhadap pasien yang kaya dan miskin. Ketika ada pasien pengguna BPJS (Badan Penyelenggara Jaminan Sosial) penanganan medis terhadap mereka tidak dilayani dengan layak bahkan kurang diperhatikan. Berbanding terbalik saat ada pasien yang kaya, mereka dilayani dengan layak, fasilitas yang memadai, dan diperlakukan dengan istimewa oleh rumah sakit. Ini merupakan contoh dari kasus penyimpangan sila keadilan sosial yang sering terjadi di masyarakat. Seharusnya pemerintah menindaklanjuti hal tersebut, karena hal ini tidak sesuai dengan nilai dari sila kelima. Keadilan tidak boleh didasarkan pada si kaya dan si miskin. Keadilan mutlak harus didapatkan oleh seluruh bangsa Indonesia tanpa memandang status jabatan atau ekonomi masyarakatnya.

Kandungan nilai pancasila pada sila ke-1 hingga ke-5 adalah harapan, tujuan, dan keinginan seluruh bangsa Indonesia yang akan dicapai dalam kehidupannya. Semua nilai tersebut seharusnya sudah diimplementasikan diberbagai segi kehidupan di masyarakat, kampus, serta negara. Agar tidak terjadi penyimpangan seperti yang telah disebutkan diatas tadi. Tidak terkecuali kepada siapapun itu asalkan ia adalah bagian dari warga negara Indonesia, mereka harus menjalankan setiap nilai pada sila-sila pancasila. Pengakuan serta penerimaan Pancasila sebagai suatu hal yang penting akan tercermin pada perilaku dan tindakan masyarakatnya. Jika pengakuan dan penerimaan tersebut sudah tercerminkan dalam segala aspek kehidupannya maka bangsa Indonesia akan tetap kuat dalam menghadapi berbagai problematika yang akan terjadi di dalam maupun luar negara. Pembukaan UUD 1945 Alinea ke-4 diterangkan bahwa Pancasila dijadikan sebagai pedoman hidup bangsa dalam menjalani segala kegiatan kehidupan berbangsa dan bernegara. Pasal-pasal dalam UUD 1945 didasarkan pada Pancasila serta hal itu dijadikan cita-cita hukum. Pengimplementasian nilai Pancasila tidak bisa dilakukan secara terpisah, hal ini disebabkan oleh Pancasila yang merupakan sebuah kesatuan yang lengkap dan utuh serta memiliki keterkaitan satu sama lain. Pelaksanaan dari sila pertama Pancasila melandasi sila ke-2 hingga ke-5. Setiap sila memiliki poinpoin penting di mana poin tersebut mengharuskan semua rakyat Indonesia agar melakukan pengaktualisasian Pancasila dalam kehidupan bermasyarakat dan bernegara.

Maka, nilai-nilai Pancasila tersebut juga melandasi setiap tindakan dan perilaku mahasiswa sebagai penjaga nilai-nilai pancasila. Mahasiswa perlu menjaga dan melaksanakan semua nilai yang terkandung dalam pancasila pada keadaan apapun termasuk pada masa wabah virus Covid-19 seperti ini. Pada masa pandemi seperti ini nilai-nilai Pancasila harus lebih direnungkan kembali terutama bagi mahasiswa. Jangan sampai nilai Pancasila diabaikan dan memudar dalam diri kita.

\section{Internalisasi Pancasila Melalui Mata Kuliah Pancasila}

Nilai dari Pancasila diinternalisasikan via mata kuliah pendidikan Pancasila di kampus sebagai character building, dapat membantu mhasiswa menjadi good citizenship serta berjiwa pancasilalis. Penerbitan Undang-undang nomor 12 tahun 2012 berkaitan dengan pendidikan tinggi yang sangat mendukung upaya 
penginternalisasian pancasila. Dalam pasal 35 ayat 3 , ada penguatan yang memfokuskan kewajiban muatan kurikulum di perguruan tinggi mesti mengampu 4 mata kuliah yang wajib termasuk salah satunya adalah mata kuliah pancasila. Kemudian, program pengadaan mata kuliah pancasila ini diterangkan lagi di dalam Surat Edaran Menteri Pendidikan Tinggi, Riset dan Teknologi Nomor. 03/M/SE/VIII/2017 tanggal 24 Agustus 2017 mengenai konsolidasi Pendidikan Pancasila dan mata kuliah wajib umum di perguruan tinggi. Di nomor 4 dijelaskan bahwa agar dapat menjadikan penerus bangsa yang cinta tanah air, memiliki karakter kuat, dan dapat menumbuhkan kepribadian bangsa Indonesia, seharusnya mata kuliah wajib ini dimantapkan menjadi salah satu upaya untuk membentuk budaya yang ada di negara ini. Berkaitan dengan beberapa hal yang telah disebutkan tadi, maka diintruksikan untuk lembaga universitas agar memasukan atau menginternalisasikan kandungan setiap poin Pancasila, budi pekerti kebangsaan serta budaya nasional saat kegiatan pembelajaran dilakukan disetiap mata kuliah yang ada dan kegiatan mahasiswa lainnya sebagai komponen dari sikap bela negara.

Ketika kegiatan pembelajaran berlangsung, dosen memaparkan secara rinci mengenai kandungan pada Pancasila serta bagaimana metode penginternalisasiannya baik diluar ataupun dalam kelas. Penginternalisasian di dalam kelas contohnya adalah, dosen memberikan penjelasan dilanjutkan pengimplementasiannya bisa juga melalui pemberian contoh kepada peserta didik mulai dari kebiasaan kecil misalnya sampah dibuang pada tempatnya, berhenti menerangkan materi ketika mendengar suara adzan berkumandang. Hal ini diharapkan supaya member teladan kepada mahasiswa bahwa kebersihan adalah tanggung jawab seluruh warga kampus dan harus berhenti sejenak dalam melakukan aktivitas untuk menghargai saat adzan. Dengan begitu, mahasiswa sudah paham mengenai etika yang ada dalam pancasila dan mereka juga sudah mengimplementasikan etika itu. (Irawan, 2014: 6) Untuk melakukan internalisasi bisa melalui 3 proses yang bisa dihubungkan dengan pengarahan kepada mahasiswa, yaitu sebagai berikut:

Yang kesatu, pentransformasian nilai sebagai keberlangsungan pendidikan untuk memberi tahu nilai yang terpuji dan tidak terpuji. Secara jelas dosen mencontohkan hal kecil mengenai pengimplementasian dari setiap poin Pancasila yang terjadi di lingkungan mahasiswa. Kedua, transaksi nilai menjadi sebuah langkah pendidikan nilai melalui proses interaksi, Dosen menerangkan nilai-nilai pada sila-sila Pancasila dengan mengadakan proses tanya jawab dengan mahasiswa. Lalu, mahasiswa diberi peluang agar dapat mencontohkan implementasi dari Pancasila dalam berkehidupan. Ketiga, transinternalisasi yaitu satu langkah lebih mendalam dari dua langkah yang telah disebutkan tadi. Langkah transinternalisasi dilakukan secara verbal serta sikap kognitif dan kepribadian, hingga akhirnya komunikasi kepribadian bisa bekerja secara aktif. Pemberian contoh-contoh sederhana seperti tidak terlambat masuk ke kelas dan sampah dibuang pada tempatnya.

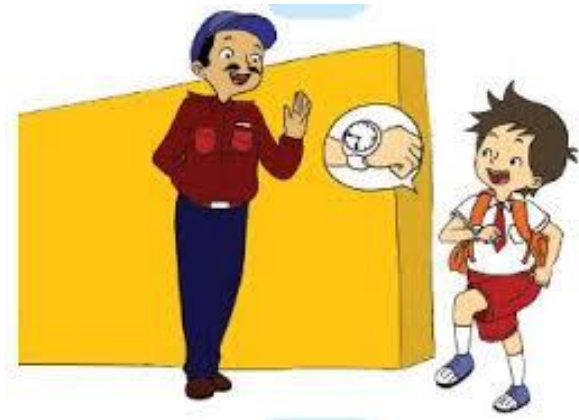

Gambar 1 


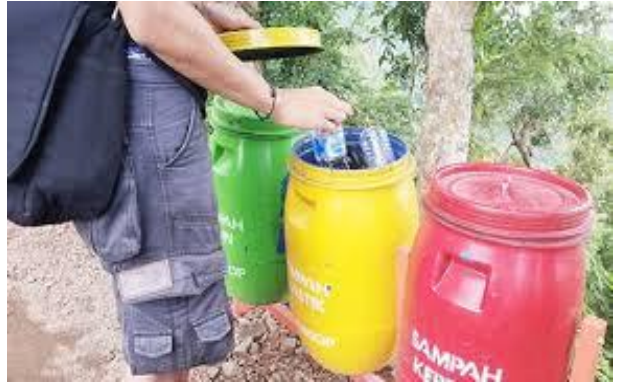

Gambar 2

Mahasiswa akan terbiasa mencontoh dan berperilaku seperti itu jika dibiasakan. Sikap saling toleransi juga perlu dosen tegaskan kepada mahasiswa agar mereka dapat menghargai satu sama lain yang berbeda suku atau ras dengannya. Hal ini dapat menciptakan keadaan yang kondusif dan saling toleransi antar mahasiswa dalam proses perkuliahan.

Pendidikan merupakan suatu usaha membentuk kepribadian manusia yang komplit melingkupi berbagai segi akademis semata yang disesuaikan untuk penguasaan ilmu dan teknologi. Peningkatan ilmu pengetahuan, ekonomi, teknologi bukan satu-satunya alasan jaminan adanya rasa kebahagiaan dalam diri manusia. (Agustian, 2008:15) Pendidikan mesti dikembangkan melalui penyerasian antara kecerdasan intelektual, spiritual dan emosional agar bisa menghadirkan sikap spiritualis didalam pendidikan yang bisa meninggalkan sebuah arti yang mendalam dalam kehidupan bangsa.

\section{KESIMPULAN}

Pancasila pemikiran serta keyakinan hidup dalam diri masyarakat Indonesia. Pancasila menciptakan negara Indonesia lebih baik lagi yang berlandaskan kepada nilai ketuhanan, nilai kemanusiaan, nilai persatuan, nilai kerakyatan dan nilai keadilan. Pentingnya penerapan nilai-nilai pancasila dalam lingkungan masyarakat perlu mendapat perhatian khusus oleh setiap masyarakat di Indonesia supaya tidak terjadi suatu hal yang dapat merugikan negara seperti halnya perpecahan. Penyimpangan akan setiap nilai pancasila juga terus terjadi di masyarakat. Pada sila satu hingga lima terdapat beberapa contoh kasus yang pernah terjadi di negara Indonesia yang menggambarkan jika pemahaman akan nilai pancasila masih kurang dalam masyarakat.

Diadakannya perguruan tinggi adalah untuk membentuk generasi bangsa yang cerdas dan unggul agar dapat mencetak generasi pemimpin bangsa. Internalisasi atau implementasi dari nilai-nilai pancasila sangat berguna dan harus terus dilaksanakan agar menciptakan para kader generasi bangsa yang cerdas serta dapat membangun bangsa ini menjadi jauh lebih baik. Contoh pengimplementasian nilai Pancasila bisa dilaksanakan melalui hal kecil seperi sampah dibuang pada tempatnya, berhenti menerangkan materi saat adzan berkumandang, saling menghargai perbedaan dan keragaman ras dan suku, dan lain sebagainya. Nilai-nilai pancasila juga harus diimplementasikan dalam berbagai aspek kehidupan di masyarakat, kampus, dan negara. Tak terkecuali siapapun itu, asalkan ia adalah warga negara, aparatur sipil, aparatur pemerintah, pejabat negara dan lain sebagainya mereka semua berpedoman kepada dasar Falsafah negara yakni pancasila.

Masyarakat bangsa Indonesia wajib menjunjung tinggi pancasila karena itu akan mencerminkan kepribadian bangsa Indonesia dan semua warga negara wajib melaksanakan setiap nilai sila-sila pancasila dengan sepenuh hati dan dengan rasa tanggung jawab. Pemahaman akan nilai pancasila juga harus ditingkatkan agar masyarakat tidak menyalahi esensi dari nilai-nilai pancasila. Perguruan tinggi atau masyarakat seharusnya dapat terus mengimplementasikan nilai-nilai pancasila 
secara tepat dalam bentuk-bentuk variatif. Jika nilai-nilai pancasila tidak dilaksanakan maka akan berimbas pada bangsa Indonesia sendiri, tidak menutup kemungkinan bahwa Indonesia akan kehilangan jati dirinya Diharapkan masyarakat dan seluruh bangsa Indonesia selalu mengaktualisasikan setiap nilai Pancasila dalam kehidupan sehari-hari.

\section{DAFTAR PUSTAKA}

Anggraini, D., Fathari, F., Anggara, J. W., \& Al Amin, M. D. A. (2020). Pengamalan nilai-nilai Pancasila bagi generasi milenial. Jurnal Inovasi Ilmu Sosial dan Politik (JISoP), 2(1), 1118.

Atikarini, D. (2018). Penyimpangan nilai nilai pancasila yang terjadi di Indonesia.

Damanhuri, D., Bahrudin, F. A., Legiani, W. H., \& Rahman, I. N. (2016). Implementasi Nilai-Nilai Pancasila Sebagai Upaya Pembangunan Karakter Bangsa. Untirta Civic Education Journal, 1(2).

Dewantara, J. A., Hermawan, Y., Yunus, D., Prasetiyo, W. H., Efriani, Arifiyanti, F., \& Nurgiansah, T. H. (2021). Anti-Corruption Education as an Effort to Form Students With Character Humanist and Law-Compliant. Jurnal Civics: Media Kajian Kewarganegaraan, 18(1), 70 81.

Dewantara, J. A., \& Nurgiansah, T. H. (2021). Building Tolerance Attitudes Of PPKN Students Through Multicultural Education Courses. Jurnal Etika Demokrasi, 6(1), 103-115.

Dewantara, J. A., Nurgiansah, T. H., \& Rachman, F. (2021). Mengatasi Pelanggaran Hak Asasi Manusia dengan Model Sekolah Ramah HAM (SR-HAM). Edukatif: Jurnal Ilmu Pendidikan, $3(2), 261-269$.

Eddy, I. W. T. (2018). Aktualisasi Nilai Pancasila Dalam Kehidupan Berbangsa Dan Bernegara. Dharmasmrti: Jurnal Ilmu Agama dan Kebudayaan, 18(1), 116-123.

Husen, H. (2020). Implementasi Permenristekdikti no 55 tahun 2018 Tentang Pembinaan Ideologi Pancasila Dalam Kegiatan Kemahasiswaan di Lingkungan Kampus: studi kasus di Universitas Negeri Semarang dan Universitas Semarang (Doctoral dissertation, UIN Sunan Ampel Surabaya).

Indriastuti, E. D. (2018). PENYIMPANGAN FUNGSI DAN NILAI-NILAI PANCASILA DALAM PENEGAKAN HUKUM SEBAGAI PEDOMAN HIDUP DALAM BERMASYARAKA. Jurnal Ilmiah Hukum Dan Dinamika Masyarakat,16(1).PENTINGNYA MENERAPKAN NILAINILAI PANCASILA DI LINGKUNGAN MASYARAKAT

Manalu, R. (2014). PERANAN GURU PKN DALAM PENERAPAN NILAI-NILAI PANCASILA BAGI SISWA DI SMA NEGERI I GAROGAKABUPATEN TAPANULI UTARA SEMESTER GENAP TAHUN PELAJARAN 2013/2014 (Doctoral dissertation, UNIMED).

Misnaini, S. M. (2018). PENGARUH PEMBELAJARAN NILAI-NILAI PANCASILA TERHADAP PRILAKU MAHASISWA DI STIK BINA HUSADA. Jurnal Ilmiah P2M STKIP Siliwangi, 5(2), 75-84.

Nurgiansah, T. H. (2020a). Fenomena Prostitusi Online Di Kota Yogyakarta Dalam Persfektif Nilai Kemanusiaan Yang Adil Dan Beradab. Jurnal Kewarganegaraan, 17(1), 27-34. https://doi.org/10.24114/jk.v17i1.14208

Nurgiansah, T. H. (2020b). Filsafat Pendidikan. In Banyumas: CV Pena Persada.

Nurgiansah, T. H. (2020c). Pelatihan Penulisan Artikel Ilmiah Bagi Mahasiswa PPKn Universitas PGRI Yogyakarta. JNPM: Jurnal Nasional Pengabdian Masyarakat, 1(1), 16-23.

Nurgiansah, T. H. (2021a). Pelatihan Penelitian Tindakan Kelas Bagi Guru Pendidikan Kewarganegaraan Di Sekolah Menengah Atas Se-Kabupaten Bantul. BERNAS: Jurnal 
Pengabdian Kepada Masyarakat, 2(1), 28-33. https://doi.org/10.31949/jb.v2i1.566 Nurgiansah, T. H. (2021b). Pendidikan Pancasila. In Solok: CV Mitra Cendekia Media.

Nurgiansah, T. H. (2021c). Petuah Pendidikan Kewarganegaraan Dalam Kontestasi Politik. AoEJ: Academy of Education Journal, 12(1), 39-47.

Nurgiansah, T. H. (2021d). The Role of Citizenship Education in Building Bantul Community Political Participation in The Pandemic Covid 19. Prosiding Seminar Nasional Pendidikan Dan Kewirausahaan, 4(1), 1-4.

Nurgiansah, T. H., \& Al Muchtar, S. (2018). Development of Student Awareness through Student Learning Model Jurisprudential in Citizenship Education. ATLANTIS PRESS, 251(Acec), 670-674. https://doi.org/10.2991/acec-18.2018.150

Octavian, W. A. (2018). Urgensi Memahami dan Mengimplementasikan Nilai-Nilai Pancasila dalam Kehidupan Sehari-hari Sebagai Sebuah Bangsa. Jurnal Bhinneka Tunggal Ika, 5(2), 125.

Riyanti, D., \& Prasetyo, D. (2020). Internalisasi Nilai-Nilai Pancasila di Perguruan Tinggi. Citizenship Jurnal Pancasila dan Kewarganegaraan, 7(2), 82-96.

Septianingsih, A. (2020). PENTINGNYA MENERAPKAN NILAI-NILAI PANCASILA DI LINGKUNGAN MASYARAKAT.

Setyosari, H. P. (2016). Metode penelitian pendidikan \& pengembangan. Prenada Media.

Sulistyarini.(2015). Pengembangan Karakter Berbasis Pancasila Melalui Pendidikan Kewarganegaraan. Jurnal Bhinneka Tunggal Ika, Volume 2(1), 1-8.

Syaripatunnuzul, N. I. M. (2019). INTERNALISASI NILAI-NILAI PENDIDIKAN AGAMA ISLAM SISWA SMA NEGERI 1 PEMULUTAN KECAMATAN PEMULUTAN KABUPATEN OGAN ILIR (Doctoral dissertation, UNIVERSITAS ISLAM NEGERI RADEN FATAH).

Zabda, S. (2017). Aktualisasi Nilai-nilai Pancasila sebagai Dasar Falsafah Negara dan Implementasinya Dalam Pembangunan Karater Bangsa.Jurnal Pendidikan Ilmu Sosial, 26(2), 106-114. 